\title{
PROLANIS IMPLEMENTATION EFFECTIVE TO CONTROL FASTING BLOOD SUGAR, HbA1c AND TOTAL CHOLESTEROL LEVELS IN PATIENTS WITH TYPE 2 DIABETES
}

\author{
Musfirah Ahmad*, Rini Rachmawaty**, Elly L. Sjattar,** Saldy Yusuf** \\ *School of Nursing, Indonesian Muslim University \\ ${ }^{* *}$ School of Nursing, Faculty of Medicine, Hasanuddin University \\ Email: musfirahmad@gmail.com
}

\begin{abstract}
Introduction: Diabetes mellitus (DM) is a global disease endemic and cause of 4.6 million deaths in the world. The Indonesian government and health insurance [BPJS Kesehatan] formulate a Chronic Disease Care Program [Program Pengelolaan Penyakit Kronis (PROLANIS)] for type 2 diabetes that aims to control the glycemic status and the risk factors of macro and microvascular complications. The purpose of this study was to analyse the correlation between the implementation of PROLANIS and fasting blood sugar, HbA1c, and total cholesterol levels in patients diagnosed with type 2 diabetes at Antang and Pampang community health centres, Makassar, Indonesia. Methods: This study used a descriptive correlation design with a cross-sectional study approach. Subjects were 40 patients diagnosed with type 2 diabetes who joined PROLANIS at PUSKESMAS Antang and Pampang, Makassar, and the sampling technique used was total sampling. The data were analysed using a correlation test to assess the significance $(p)$, the direction $(+/-)$, and the strength of the correlation $(r)$. The implementation of PROLANIS was measured by using the observation sheets developed based on BPJS Kesehatan criteria, while the laboratory checked the fasting blood sugar, HbA1c, and total cholesterol levels. Results: The mean of the implementation of PROLANIS was 15.05 (SD \pm 5.62), while the mean levels of fasting blood sugar, HbA1c, and total cholesterol were as follow: $191.80 \mathrm{mg} / \mathrm{dL}$ (SD \pm 85.15 ); $8.4 \%$ ( $\mathrm{SD} \pm 2.08$ ); and $192.87 \mathrm{mg} / \mathrm{dL}(\mathrm{SD} \pm 45.07$ ). Using the Spearman's rho test, the study result showed that there was a significant and negative correlation between the implementation of PROLANIS and the levels of fasting blood sugar ( $p=0.001$; $r=-0.724)$, HbA1c $(p=0.001 ; r=-0.870)$, and total cholesterol $(p=0.029 ; r=-0.35)$ in patients diagnosed with type 2 diabetes at Puskemas Antang and Pampang, Makassar. Conclusions: The optimal implementation of PROLANIS is very effective for controlling the levels of fasting blood sugar, HbA1c, and total cholesterol in patients with type 2 diabetes.
\end{abstract}

Keywords: Fasting Blood Sugar, HbA1c, PROLANIS, Primary Health Centre, Type 2 Diabetes.

\section{INTRODUCTION}

Diabetes mellitus (DM) can be defined as a group of metabolic diseases characterised by hyperglycemia resulting from defects in insulin secretion, insulin action or both. Chronic hyperglycemia in diabetes is associated with long-term damage, dysfunction, and failure of various organs, especially the eyes, kidneys, nerves, heart, and blood vessels (Abdel-Rahman 2011). Besides being a metabolic disease, diabetes is also a global disease endemic. The incidence of diabetes globally, it is estimated, will increase from 366 million to 552 million in 2030 and will present itself as a major health challenge that can be shown by the data of global DM (Shaw, Sicre \& Zimmet 2010).

If no action is taken, it is estimated the number will rise to 552 million in 2030 and will be the cause of 4.6 million deaths (Federation 2011). In Indonesia, the number of people with diabetes is as many as 292,715 people, or about $1.8 \%$ of the total participants in Social Health Insurance (BPJS Kesehatan 2015).
The number of cases of diabetes in the province of South Sulawesi in 2014 (282 patients) consisted of reported DM (207 patients), unreported DM (160 patients) and Dependent DM on insulin (72 patients) (Sul-Sel 2014). Increasing cases of diabetes occurred in Makassar. In 2012, DM was ranked the fifth leading cause of death with 191 deaths (Dinkes Kota Makassar 2012), while in 2013 it rose to fourth with 217 (Dinkes Kota Makassar 2013). Data for DM patients at Puskesmas Antang Makassar, from January to December 2015 showed 725 patients so that the average number of patients with type 2 diabetes per month was estimated at 61 people, while in January and February 2016 there were at least 136 people and the average number of patients per month was 68 people (Rekam Medik Puskesmas Antang Kota Makassar 2016).

Prevention of chronic complications is not only through controlling blood glucose levels itself but needs good diabetic control. Control of diabetes should be done thoroughly, including 
blood glucose, HbA1c, lipid (cholesterol LowDensity Lipoprotein (LDL), high-density lipoprotein (HDL), and triglycerides (Semiardji, 2003). Therefore, the development of new strategies to improve diabetes control and its complications would be very helpful (Bianchi, Miccoli, Daniele, Penno \& Del Prato 2009). In Indonesia, one of the new strategies developed is the management program of chronic diseases (PROLANIS). PROLANIS was developed by BPJS. The main objective of PROLANIS is to reduce the risk of complications and achieve a better quality of life with the use of costeffective and rational measures. The PROLANIS program is a system of governance of health services and health education for social health insurance participants who suffer from hypertension and type 2 diabetes mellitus to achieve the optimal quality of life independently (Idris 2014). The implementation of PROLANIS in Indonesia took place in 2010. This program helps chronic disease management with an integrated promotive and preventive action format. One of the chronic diseases handled at this time is type 2 diabetes mellitus (Idris 2014).

The activities of PROLANIS itself consist of a medical consultation for PROLANIS participants: consultation schedules agreed between participants with health facility managers, high-risk educational clubs (PROLANIS Club) which are an activity to improve health knowledge in an effort to restore the disease and prevent a resurgence of the disease and improve the health status of PROLANIS attendees, reminders or activities to motivate participants to make regular visits to health facilities through a consultation schedule reminding them to go to the health facilities manager, and home visits such as service activities of home visits of PROLANIS participants for the provision of information /self health education and the environment for PROLANIS participants and their families (BPJS Kesehatan 2015).

Previous research (Alexander 2012) has confirmed the effectiveness of the PROLANIS program. Nonetheless, a PROLANIS effectiveness evaluation in health centers is still limited. Therefore, this study aimed to analyse the correlation between the implementation of PROLANIS with fasting blood sugar, HbA1c and total cholesterol in patients with type 2 diabetes mellitus in Puskesmas Antang and Pampang Makassar. It can be concluded that PROLANIS is very effective in controlling health status and improving the quality of life of patients with type 2 diabetes mellitus.

Based on the explanation, researchers were interested in analysing the correlation of PROLANIS implementation with fasting blood sugar, HbA1c, and total cholesterol in type 2 diabetes mellitus at Antang and Pampang community health centres Makassar.

\section{METHODS}

This study was a quantitative study with a descriptive correlational design, using a crosssectional study approach for the collection of data. The study was conducted during one month at Antang and Pampang community health centres Makassar. The population in this study was made up entirely of patients with type 2 Diabetes mellitus, male and female who were PROLANIS participants in Makassar, as many as 66 (37 patients in Antang community health centres and 29 patients in Pampang community health centres). Calculation of the number of samples shows 64 people, but the samples obtained in this study were 40 people. 24 patients dropped out due to the complications of coronary heart disease (CHD) and as many as 12 persons were referred to the hospital, five people refused to respond and seven people were never present during the study.

The samples in this study were patients with type 2 diabetes, PROLANIS participants at Antang and Pampang community health centres Makassar who met the inclusion criteria: male or female $\geq 35$ years old, suffered no injuries from diabetes and were willing to participate in this study and signed the informed consent. The exclusion criteria: patients with concomitant diseases such as acute renal failure or chronic renal failure, heart failure/cardiac arrhythmia, chronic liver disease/acute lung tumours or other malignancies, gastrointestinal disease, and patients who were not willing to participate in the study.

Data were analysed using univariate and bivariate analysis. For numerical data in the form of respondent characteristics such as age, 
diagnosed with type 2 diabetes, the duration of being a participant in PROLANIS, and the research variables, namely, the implementation PROLANIS, fasting blood sugar, HbAlc and total cholesterol levels using the mean and standard deviation ( $\pm \mathrm{SD}$ ), whereas categorical data such as gender, occupation and education are presented in the form of $\mathrm{n}(\%)$. Data normality test was done using the Shapiro-Wilk test. Bivariate analysis used the correlative method. If the types of data are numerical data and normally distributed, the Pearson Correlation test was used, whereas when the data type is not normally distributed the Spearman's test was used (Dahlan 2015).

This study has received ethical approval from the Ethical Comission of the Faculty of Medicine Universitas Hassanuddin with number 1048/H4.8.4.5.31/PP36-KOMETIK/2016, in September 20th, 2016.

\section{RESULTS}

Out of 40 respondents, most respondents were women $(67.5 \%)$, did not work or were house wives $(65 \%)$, had a level of education of junior high school (27.5\%), senior high school $(25.0 \%)$ and university $(27.5 \%)$. The average age of respondents was 55.83 years ( \pm SD 8:04), old diagnosed with Type 2 diabetes mellitus is 10.85 years (SD \pm 4.63 ), and the duration average following PROLANIS program that is 17.55 months (SD \pm 11.64 ) (Table 1).

The average score of PROLANIS implementation was 15.05 ( $\mathrm{SD} \pm 5.62$ ), fasting blood sugar $191.80 \mathrm{mg} / \mathrm{dl}(\mathrm{SD} \pm 85.15), \mathrm{HbA} 1 \mathrm{c}$ was $8.36 \%$ ( \pm SD 2:08), and total cholesterol $192.87 \mathrm{mg} / \mathrm{dl}(\mathrm{SD} \pm 45.07)$. This distribution was based on the implementation of PROLANIS, fasting blood sugar, HbA1c and total cholesterol as can be seen in Table 2.

Table 1 Distribution of Individual Characteristics

\begin{tabular}{lcc}
\hline \multicolumn{1}{c}{ Variable } & Frequency $(\mathbf{n}=\mathbf{4 0})$ & Percentage (100\%) \\
\hline Age (years) mean $( \pm$ SD) & 55.82 & 8.04 \\
Gender & & \\
$\quad$ Male & 13 & 32.5 \\
$\quad$ Female & 27 & 67.5 \\
Employment & 1 & 2.5 \\
$\quad$ Farmers/ Labour & 6 & 15.0 \\
Enterpreanurer & 7 & 17.5 \\
Civil Servant / TNI-Police / Retired & 26 & 65.0 \\
$\quad$ Unemployed/ House Wife & & \\
Education & 1 & 2.5 \\
$\quad$ No School / Not completed primary school & 7 & 17.5 \\
$\quad$ Elementary School & 11 & 27.5 \\
$\quad$ Junior High School & 10 & 25.0 \\
$\quad$ Senior High School & 11 & 27.5 \\
$\quad$ University & 10.85 & 4.63 \\
Old diagnosed with type 2 diabetes (years) mean $( \pm$ SD) & 17.55 & 11.64 \\
Duration Following PROLANIS (months) mean $( \pm$ SD) & & \\
$\quad$
\end{tabular}

Table 2. Distribution of respondents by the Implementation of PROLANIS, Fasting Blood Sugar, HbA1c, and Total Cholesterol in Patient with Type 2 Diabetes Mellitus $(n=40)$

\begin{tabular}{lcc}
\hline \multicolumn{1}{c}{ Variable } & Mean & 土SD \\
\hline PROLANIS implementation & 15.055 & 62 \\
Fasting Blood Sugar & 191.80 & 85.15 \\
HbA1c & 8.37 & 2.08 \\
Total Cholesterol & 192.87 & 45.07 \\
\hline
\end{tabular}


Prolanis Implementation to Control Fasting Blood Sugar (Musrifah Ahmad et.al.)

Table 3. Relationship of PROLANIS Implementation and Fasting Blood Sugar, HbA1c and Total Cholesterol in Patients with Type 2 Diabetes Mellitus

\begin{tabular}{ccccccc}
\hline \multirow{2}{*}{ Variable } & \multicolumn{2}{c}{ Fasting Blood Sugar } & \multicolumn{2}{c}{ HbA1c } & \multicolumn{2}{c}{ Cholesterol } \\
\cline { 2 - 7 } & $\boldsymbol{r}$ & $\boldsymbol{p}$ & $\boldsymbol{R}$ & $\boldsymbol{p}$ & $\boldsymbol{R}$ & $\boldsymbol{p}$ \\
\hline PROLANIS Implementation & -0.72 & 0,001 & -0.87 & 0.001 & -0.35 & 0,029 \\
Medical Consultation & -0.66 & 0,001 & -0.77 & 0,001 & -0.34 & 0,031 \\
Activity Group & -0.68 & 0,001 & -0.82 & 0,001 & -0.33 & 0,037 \\
SMS Gateway & -0.7 & 0,001 & -0.81 & 0,001 & -0.37 & 0,021 \\
Home Visit & -0.39 & 0.047 & $-0: 49$ & $0: 01$ & $-0: 36$ & 0062 \\
\hline
\end{tabular}

Based on the Spearman rho test in Table 3 , the data showed that there is a relationship between PROLANIS implementation with fasting blood sugar in patients with type 2 diabetes mellitus at Antang and Pampang community health centres Makassar, with a significance value of $(p) 0.001$ with a negative correlation direction $(\mathrm{r}=-0724)$ and the strength of a strong correlation $(\mathrm{r} 2=0.52)$. The correlation between the activity of PROLANIS, namely in terms of medical consultation, group activities, SMS gateway, and home visit with fasting blood sugar also showed a correlation ( $\mathrm{p}$ $=0.001 ; 0.001 ; 0.001 ;$ and 0.047$)$ with the negative correlation direction and the strength of strong and moderate correlation $(\mathrm{r}=-0.66$; $0.68 ;-0.70$; and -0.39 ). This means that with the maximum implementation of PROLANIS the lower the levels of GDP with diabetes mellitus type 2. This relationship can be seen in Figure 1.

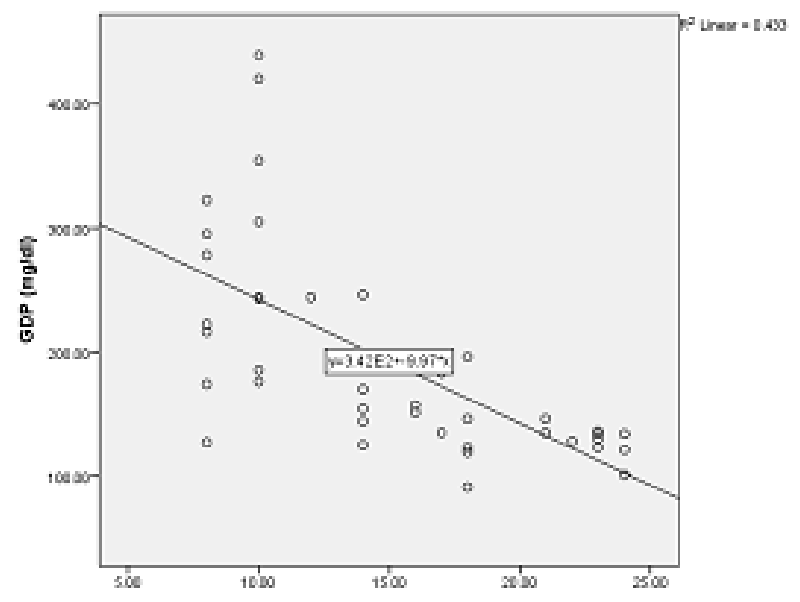

Figure1. Correlationof PROLANIS Implementation and Fasting Blood Sugar
Based on the Spearman rho test in Table 3, the data showed that there is a relationship between the implementation of PROLANIS with HbA1c with a significance value of $(p) 0.001$ with a negative correlation direction (-0.87) and the strength of strong correlation $(\mathrm{r} 2=0.76)$. The correlation between the activity of PROLANIS was namely in terms of medical consultation, group activities, SMS gateway, and home visits with HbA1c also showing a correlation ( $p=$ $0.001 ; 0.001 ; 0.001$; and $0: 01)$ with a negative correlation direction and a strength of strong and moderate correlation $(\mathrm{r}=-0.77 ;-0.82 ;-0.81$; and -0.49 ). This means that with the maximum implementation of PROLANIS the lower the levels of HbA1c with type 2 diabetes mellitus. This correlation can be seen in Figure 2.

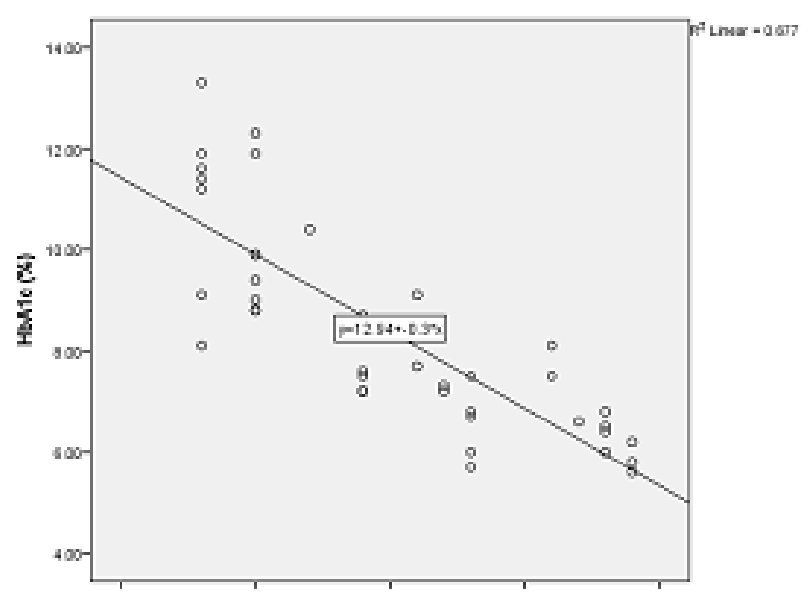

Figure 2. Correlation of PROLANIS Implementation and HbA1c Levels 


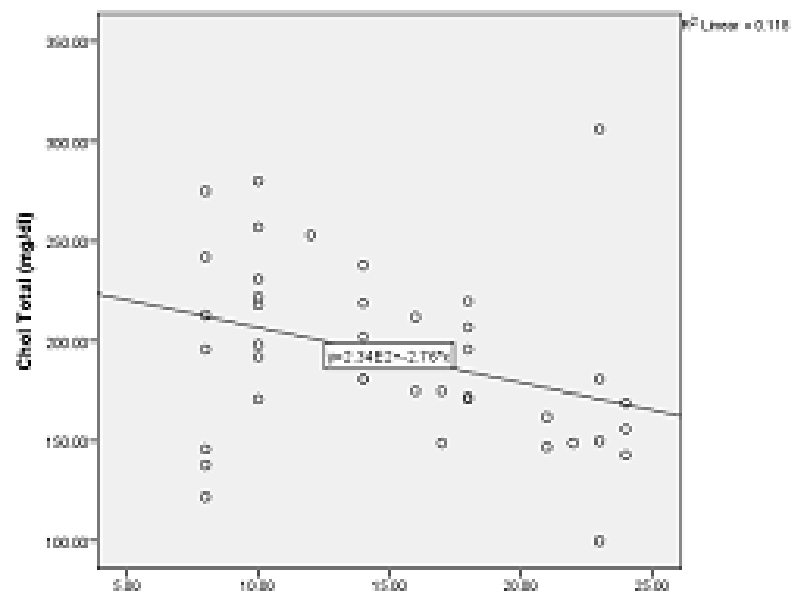

Figure 3. Correlation Implementation PROLANIS and Total

Based on Table 3, the spearman's rho test data showed that there is a relationship between the implementation of PROLANIS with total cholesterol levels with a significance value of (p) 0.029 with a negative correlation direction ( $\mathrm{r}$ $=-0.35$ ) and the strength of a weak correlation $(\mathrm{r} 2=0: 11)$. The correlation between the activity of PROLANIS was namely in terms of medical consultation, group activities, and SMS gateway with total cholesterol also showing a correlation $(\mathrm{p}=0.031 ; 0.037$; and 0.021$)$ with a negative correlation direction and the strength of moderate correlation $(\mathrm{r}=-0.34 ;-0.33$; and 0.37). However, there is no correlation between a home visit with total cholesterol levels with $p$ $=0.062$. This means that with the maximum implementation of PROLANIS the lower the total cholesterol with type 2 diabetes mellitus. This correlation can be seen in Figure 3.

\section{DISCUSSION}

PROLANIS Implementation is one of the government programs cooperating with BPJS to encourage participants with chronic illness to achieve optimal quality of life so as to prevent complications of the disease (BPJS Kesehatan 2015). PROLANIS activities are carried out at Antang and Pampang community health centres Makassar, held every week on Saturday mornings. According to researcher observations, PROLANIS activity is ongoing and offers routine activities and is strongly supported by the clinic by providing the facilities needed for these activities and often making activities to strengthen kinship between participants and the public health centres such as holiday activities together. The clinic crew was there as a participant in PROLANIS so that it became an example or model for other participants. According to Green, \& Kreuter (1999) the habit, model, and the support of the environment, in this case the health care facilities, forms a positive attitude for an individual. The positive behaviour of patients with type 2 diabetes mellitus leads to an awareness of the importance of maintaining a diet, control treatment and regular physical activity, medical consultations and all of that could be obtained if the participants are active in following PROLANIS activities.

In addition, according to the theoretical concepts of precede proceeds say that the individual behaviour is influenced by several predisposing factors, enabling and reinforcing. Predisposing factors reflected in the characteristics of respondents, supporting factors described by the infrastructure support in implementing PROLANIS and reinforcing factors reflected in the attitudes and behaviour of health centre officers who became a model for the implementation of PROLANIS. Good behaviour or lifestyle will both improve an individual's health status (Green \& Kreuter, 1999). Health status refers to the control of blood sugar levels and risk factors for complications. This study shows that there is a strong negative correlation between the implementation of PROLANIS and fasting blood sugar in patients with type 2 diabetes mellitus which means that with the maximum implementation of PROLANIS the lower the fasting blood sugar levels of type 2 diabetic patients.

Activity in the implementation of PROLANIS activities includes medical consultations/education, home visits, reminders, club activities and monitoring of health status. Medical consultation exercises undertaken by participants along with health facility managers began with a contract time with medical personnel. Consultation includes a prognosis of disease, complaints about the health problems of participants and drugs control (BPJS Kesehatan 2015). This study shows there is a strong negative correlation between medical 
Consultation with fasting blood sugar levels of respondents with a value of $p<0.05$ which means that with the maximum value of the medical consultation exercise the lower the fasting blood sugar in type 2 diabetic patients by Salistyaningsih. Previously Salistyaningsih, Puspitawati \& Nugroho (2011) showed a link between adherence in consuming the oral hyperglycemia drug (Obat Hiperglikemi Oral $(\mathrm{OHO})$ ) with blood glucose levels in patients with type 2 diabetes mellitus in PuskesmasUmbulharjo II Yogyakarta where patients were wayward in drinking $\mathrm{OHO} 86$ times at a risk od increasing blood sugar levels compared with patients who obeyed.

Hapsari (2014) also examined the treatment of type 2 diabetes Mellitus. Research results indicate a negative and weak correlation with $p<0.05 d$ and $r=-0064, r^{2}=0.004$ between compliance in taking the drug with blood sugar levels. This means that the higher value of compliance in taking the drug, the lower the blood sugar level which indicates the success of the therapy. Besides Mona, Bintanah \& Astuti (2012) also examined the association of frequency of nutritional consultation with compliance diet and blood sugar levels in people with diabetes mellitus type 2 at the outpatient hospital Tugerejo Semarang which showed a significant correlation between the frequency of nutritional counseling and compliance with diet, and there is a correlation between diet compliance with the patient's blood sugar levels.

Club activity is an activity to improve health knowledge to restore the disease and prevent the return of disease and improve the health status of PROLANIS participants with physical activity (BPJS Kesehatan 2015). Physical activity is held every week on Saturday mornings and health education on diet and type 2 diabetes treatment is carried out two times a month. Based on the results of research conducted there is a strong negative correlation between the activity and the group with a blood sugar value of $p=0.001$ and $r=-0.68$, which means that the higher the value of the implementation of PROLANIS the lower the fasting blood glucose of type 2 diabetic patients.

Other studies conducted by Putri \& Isfandiari (2013) which aim to determine whether there is a correlation between the application of the 4 pillars controlling diabetes with the average of blood glucose levels indicate that there is a relationship between absorption education $(p=0.031)$, diet control $(p=0.002)$, sport $(\mathrm{p}=0.017)$ and medication adherence $(\mathrm{p}=$ 0.003 ) with the average of blood sugar levels.

Reminders or SMS gateway is an activity to motivate participants to make regular visits to the health facility through a recall schedule (BPJS Kesehatan, 2015). SMS gateway activity at Puskesmas Antang and Pampang Makassar includes recording mobile numbers of participants, enabling a communication network (JARKOM) between participants and health centres, and evaluation of the activity of participants in a communication network and enabling the participants to understand the content given. Hopefully, by the communication network formed, PROLANIS participants with type 2 diabetes are able to access information about the PROLANIS activities to be carried out whether medical consultations, drug taking schedules or group activities that are held every week. Based on the results of the research conducted there is a strong negative correlation between the SMS gateway with fasting blood sugar for type 2 DM patients at Antang and Pampang community health centres Makassar with $p=0.001$ and $r=-0.68$, which means that the higher the value of the implementation of PROLANIS the lower the fasting blood sugar of people with type 2DM.

A home visit is a service activity visitation to the home of PROLANIS participants for the provision of information/self-health education and the environment for PROLANIS participants and their families. Terms of these activities include home visits for patients newly enrolled, patients who were not present at PROLANIS activities for three months in a row, and those who have recently completed in hospitalisation. The results of the home visit are recorded in the book of health monitoring and reported to the clinic and BPJS (BPJS Kesehatan 2015). From the data obtained during the study, the implementation of the home visits conducted at Puskesmas Antanghas have largely been carry out from the 24 patients with type 2 diabetes: 22 participants had received home visits and only two people never got home visits. Of the 22 
participants, only three people who get a home visit of new participants registered and been hospitalised because of the deteriorating health and the 19 other participant visitations were to enroll a new patient in PROLANIS. But the problem is that for every home visit, there was no record of activity or actions taken by health officers; information was only presented in the report form such as ever or never visited and dates of visits for the evaluation report.

In contrast to the Puskesmas Antang, PROLANIS participants with type 2 diabetes at Puskesmas Pampang only occasionally get a home visit. Out of 16 patients with type 2 diabetes only five people ever got a home visit and that too was for newly registered participants. The rest (11 participants) never got home visits, and no record of the activities carried out at home visits are available in the patient health monitoring book. This is what underlies the fact that despite the results obtained there is a negative correlation between home visits with fasting blood glucose levels of type 2 diabetes patients in Antang and Pampang community health centres Makassar with $p=$ 0.047 , but very weak correlation obtained, namely $r=-0.39$ and $r^{2}=0: 15$. This means, only $15 \%$ of the variation in home visits affects fasting blood glucose levels of type 2 diabetes patients at Antang and Pampang community health centres Makassar.

Hemoglobin HbA1C test results are a highly accurate single examination to assess long-term glycemic status and are useful for all types of DM. This examination is beneficial for patients who need glycemic control. Increased levels of HbA1c> $8 \%$ indicate uncontrolled diabetes and risk of long-term complications such as nephropathy, retinopathy, or cardiopathy (Soewondo, 2005). The research data showed that average A1C type 2 DM patients at Puskesmas Antang and Pampang Antang uncontrolled Makassar City are $8.37 \%$. A $1 \%$ decrease in $\mathrm{HbA} 1 \mathrm{c}$ will reduce complications by 35\% (Soewondo, 2005).

This research was also supported by research conducted by Alexander (2012), which aims to analyse the effectiveness of the PROLANIS in order to control the health status of patients with type 2 diabetes mellitus, who found that there are differences in cholesterol reduction, blood pressure systole and diastole, HbAlc, and improved quality of life significantly in the intervention group compared with the control group ( $\mathrm{p}<0.05)$, but there is no significant difference in BMI reduction between the intervention and control groups, with $\mathrm{p}>$ 0.05. Syuadzah (2015) aimed to examine the association between adherence to following the activities of PROLANIS with HbA1c levels in patients with type 2 diabetes mellitus in Surakarta and showed a significant association $(\mathrm{p}=0: 04)$. It can be concluded that PROLANIS is very effective in controlling health status and improving the quality of life of patients with diabetes mellitus type 2 (Burns\& Grove 2011).

Behaviour that is promoted is awareness of the importance of keeping your diet, medication control and regular physical activity, medical consultations and all that could be obtained if a participant is active in all the activities PROLANIS follows. The research done showed that type 2 diabetes patients at Antang and Pampang community health centres Makassar actively carry PROLANIS with an average value of 15.05 or over half of the total value of a maximum observation sheet which is 25. The activity in PROLANIS implementation includes activities in the medical consultation/education, home visits, reminders, club activities and monitoring of health status. The partners in the medical consultation exercise that led to the consultation activities undertaken by participants along with health facility managers in this case are Antang and Pampang community health centres which began with a contract time with medical personnel. These activities include consultation regarding the prognosis of the disease, consultation regarding other complaints about the health problems of participants and the most important is control of drugs (BPJS Health, 2015)

Based on research done there is strong and negative correlation between medical consultation with HbA1c levels in diabetic patients with type 2 in Antang and Pampang community health centres in Makassar with $p<0.05$ which means that with the maximum value of the implementation of a medical consultation, the lower the HbA1c levels in type 2 diabetic patients. The research was also supported by research conducted by Mona, 
Bintanah and Astuti (2012), which aims to examine the relationship between frequency of nutritional consultation with compliance diet and blood sugar levels in people with diabetes mellitus type 2 at an outpatient hospital Tugerejo Semarang, which showed a significant relationship between frequency nutrition consultation with diet adherence and a relationship between diet compliance with patient's blood sugar levels.

Another study about the treatment of diabetes type 2 was also performed by Yoga, Julianti \& Pramono (2011), aimed at assessing the relationship between the application of the 4 pillars of control of DM with the successful management of patients with diabetes type 2, where the success of the measure of $\mathrm{HbAlc}$ levels of patients indicates that medication adherence regularly provided statistically significant results with $p=0.05$.

Group activity is an activity of physical activity and health education to improve patients' knowledge to restore the disease and prevent the return of disease and improve the health status of participants PROLANIS (BPJS Health, 2015). Research by testing using Spearmen's rho shows that there is a negative and strong relationship between the activities of the group with blood sugar levels in diabetic patients with type 2 at Antang and Pampang community health centres Makassar with $p=$ 0.001 and $\mathrm{r}-0.68$, which means that the higher the value of the implementation of PROLANIS the lower the HbA1c in type $2 \mathrm{DM}$ patients.

Physical activity is held every week on Saturday morning at Antang and Pampang community health centres Makassar implemented in the form of gymnastic fitness for the elderly. The results of research conducted by Yoga, Julianti \& Pramod (2011) aimed to assess the correlation between the implementation of the 4 pillars of control of DM with the successful management of patients with diabetes type 2, where the success of the measure of HbAlc levels of patients showed that the regularity of exercise has a significant influence on the success of management of type 2 diabetes with a significant value of $\mathrm{p}=0.00$; and research by Ramadhanisa, Larasati, \& Mayasari (2013) aimed to determine the relationship of physical activity with the HbA1c of people with type 2 diabetes mellitus in dr. H. Abdul Moeloek Bandar Lampung; this showed a significant association between physical activity levels of HbA1c, with $\mathrm{p}=0.001$. It can be concluded that physical activity is very good for controlling blood sugar levels which can be viewed through an $\mathrm{HbA} 1 \mathrm{c}$.

In addition to physical activity in group activities education about diet and treatment of patients with diabetes type 2 were also included which, according to the results of research conducted by Harum, Larasati, \& Zuraida (2013) aimed to show the relationship between high dietary fibre with levels of $\mathrm{HbAlc}$ in patients with DM type 2 in a hospital clinical pathology laboratory Dr.Hi.AbdulMoeloek Lampung province using the chi-square method; it showed a significant relationship between a high fibre diet with $\mathrm{HbA1c}$ levels (p-value $0.001)$.

Total cholesterol level is the amount of cholesterol found in the blood which includes LDL, HDL, and TGL. Cholesterol levels are closely linked to fatty deposits in the human body. If in the inside of the body a person has a lot of fat it is likely to cause various diseases such as heart disease and diabetes. For patients with DM, the amount of fat in the body of excess will aggravate the situation and accelerate the onset of complications due to fat being very easily broken down into glucose in the blood due to insulin resistance. Based on the results of research conducted by Ekawati (2012) there is a significant correlation between fasting blood sugar and cholesterol levels of triglycerides in the blood in patients with DM which is not well controlled in Clinical Hospital Jombang.

As is already known, cholesterol is strongly influenced by physical activity and the food intake of a person. According to research conducted by Anam (2010) regular dietary interventions and physical activity or sports as often as 3 times a week for 8 consecutive weeks can lower LDL cholesterol levels in the blood to $13.5 \mathrm{mg} / \mathrm{dl}$ and boost levels of HDL to 7.5 $\mathrm{mg} / \mathrm{dl}$. Research conducted by Sari (2014) with pre-post design for 6 weeks showed a difference in total cholesterol before and after aerobic exercise $(p=0.009)$. According to the analysis of the researchers, the underlying average total 
cholesterol levels of PROLANIS participants with type 2 diabetes patients at Puskesmas Antang and Pampang Makassar is within the normal range of $192.87 \mathrm{mg} / \mathrm{dl}$ because the average length for which these participants have followed PROLANIS activities is less over 18 months or for 72 weeks.

Physical activity and dietary interventions are one of the activities of PROLANIS. PROLANIS group activity is an activity to improve health knowledge to restore the disease and prevent the return of disease and improve the health status of participants of PROLANIS with physical activity (BPJS Health 2015). Physical activity is held every week on Saturday mornings and health education on diet and type 2 diabetes treatment is carried out twice a month. Based on the results of research conducted, there is a negative and weak relationship between activity with total cholesterol levels of Type 2 diabetes patients at Antang and Pampang community health centres Makassar with $p=0.037$ and $\mathrm{r}-0.33$, which means that the higher the value of the implementation of PROLANIS the lower the total cholesterol levels in patients with type 2 diabetes.

In addition to group activities, other activities included in the PROLANIS implementation are medical consultations, reminder or SMS gateway and home visits. The medical consultation exercise where the consultation activities are undertaken by participants along with health facility managers in this case are held at the health centres and Pampang Antang which began with a contract time with medical personnel. These activities include consultation regarding the prognosis of the disease, consultation regarding other complaints about the health problems of participants and most importantly the control of drugs (BPJS Health 2015). Physical activity is held every week on Saturday mornings and health education on diet and type 2 diabetes treatment is carried out twice a month. Based on the results of the research conducted there is a negative relationship between activity and weak group with total cholesterol levels of type 2 diabetes patients in primary health centres and Pampang Antang Makassar City with $\mathrm{p}=0.037$ and $\mathrm{r}-0.33$, which means that the higher the value of the implementation of PROLANIS the lower the total cholesterol levels in patients with type 2 diabetes.

Reminders or SMS gateway are activities to motivate participants to regularly visit the health facility through a recall schedule (BPJS Kesehatan, 2015). SMS gateway activity at Puskesmas Antang and Pampang includes recording mobile numbers of participants, enabling a communication network (JARKOM) between participants and health centres, and evaluation of the activity of participants in JARKOM and enabling participants to understand the content of the communication network used. Hopefully, through the communication network formed, PROLANIS participants with type 2 diabetes are able to access information about the activities to be carried out either through PROLANIS in terms of medical consultation, drug taking schedules and group activities that are held every week. Based on the results of research conducted there is a negative correlation between the weak and SMS gateway with total cholesterol levels of type 2 diabetes patients at Antang and Pampang community health centres Makassar with a value of $p=0.021$ and $r=-0.37$, which means that the higher the value of PROLANIS implementation the lower the total cholesterol levels in patients with type 2 diabetes.

Home visits at Puskesmas Antang and Pampang, based on the previous explanation, have not run optimally. According to the researchers, this is why the assumption based on the Spearman's rho test found that there is no correlation between home visits with total cholesterol levels in patients with type 2 diabetes mellitus at Puskesmas Antang and Pampang Makassar with $\mathrm{p}=0.062$.

The Fourth PROLANIS activity shows that this event is a program that is highly complex and integrated as it includes activities associated with cholesterol levels in patients with type 2 diabetes. This is what underlies the fact that the Spearman's rho test showed that, although weak, there is still a negative relationship between PROLANIS implementation with total cholesterol levels. The higher the value for implementation of PROLANIS the lower total cholesterol levels in 
patients with type 2 diabetes mellitus and at Puskesmas Antang and Pampang Makassar.

\section{CONCLUSIONS}

Maximum PROLANIS implementation is very effective in controlling fasting blood sugar levels, HbA1c and total cholesterol in patients with type $2 \mathrm{DM}$ thus indirectly preventing complications. Therefore, it is suggested that PROLANIS should be implemented in each community health centre and primary health centre and comply with the standards set by government health insurance. The evaluation process of PROLANIS focused on the quality of implementation; the results can be seen from the impact and benefits to the target group in terms of the glycemic status of patients with type 2 diabetes in the form of measurable data.

\section{REFERENCES}

Abdel-Rahman, Z., 2011. The effects of antioxidants supplementation on haemostatic parameters and lipid profiles in diabetic rats. Journal of American Science, 7(3).

Bianchi, C., Miccoli, R., Daniele, G., Penno, G., \& Del Prato, S., 2009. Is there evidence that oral hypoglycemic agents reduce cardiovascular morbidity/mortality? yes. Diabetes Care, 32(2), pp.342-348.

BPJS Kesehatan, 2015. Panduan Praktis Prolanis (Program Pengelolaan Penyakit Kronis), Jakarta: Badan Penyelenggara Jaminan Sosial Kesehatan.

Burns, N., \& Grove, S., 2011. Understanding Nursing Research, Building and EvidenceBased Practice 5th ed., USA: Elsevier.

Dahlan, M., 2015. Statistik untuk Kedokteran dan Kesehatan, Deskriptif, Bivariat, dan Multivariat Dilengkapi Aplikasi Menggunakan SPSS 6th ed., Jakarta: Epidemologi Indonesia.

Dinkes Kota Makassar, 2013. Profil Kesehatan Kota Makassar, Makassar: Dinas Kesehatan Kota Makassar.

Dinkes Kota Makassar, 2012. ProfilKesehatan Kota Makassar, Makasar: Dinkes Kota Makasar.

Federation, I.D., 2011. Diabetes Evidence Demands Real Action From The Un
Summit On Non-Communicable Diseases. Available at: www.idf.org: www.idf.org/diabetes-evidence-demandsreal action-un-summit-non-communicablediseases [Accessed January 16, 2016].

Green, L.W., \& Kreuter, M., 1999. Health Promotion Planning: An Educational and Ecological Approach 3, ed., Mountain View, CA: Mayfield Publishing Co.

Hapsari, P., 2014. Hubungan Antara Kepatuhan Penggunaan Obat dengan Keberhasilan Terapi pada Pasien Diabetes Mellitus di RS X Surakarta, Surakarta: Fakultas Farmasi Universitas Muhammadiyah Surakarta.

Harum, A., Larasati, \& Zuraida, R., 2013. Hubungan Diet Serat Tinggi Dengan Kadar HBA1C Pasien Diabetes mellitus Tipe 2. Medical Journal of Lampung University, 2(4).

Idris, F., 2014. Pengintegrasian Program PreventifPenyakit Diabetes mellitus Tipe 2 PT Askes (Persero) ke BPJS Kesehatan. $J$ Indon Med Assoc, 64(3), pp.115-121.

Mona, E., Bintanah, S., \& Astuti, R., 2012. Hubungan Frekuensi Pemberian Konsultasi Gizi dengan Kepatuhan Diit. JURNAL GIZI UNIVERSITAS MUHAMMADIYAH SEMARANG, 1(1).

Putri, N.H., \& Isfandiari, M., 2013. HubunganAktivitasFisikdenganKadar HBA1C Pasien. Medical Journal of Lampung University, 1(2), pp.234-243.

Ramadhanisa, A., Larasati, \& Mayasari, D., 2013. Hubungan Aktivitas Fisik dengan Kadar HBA1C Pasien. Medical Journal of Lampung University, 2(4).

Rekam Medik Puskesmas Antang Kota Makassar., 2016. Laporan Rekam Medik Puskesmas Antang Kota Makassar, Makasar: Puskesmas Antang.

Salistyaningsih, W., Puspitawati, T., \& Nugroho, D., 2011. Hubungan Tingkat Kepatuhan Minum Obat Hipoglikemik Oral dengan Kadar Glukosa Darah pada Pasien Diabetes mellitus Tipe 2. Berita Kedokteran Masyarakat, 27(4), pp.215221.

Sari, A., 2014. Efektivitas pelaksanaan Program Pengelolaan Penyakit Kronis (Prolanis) dalam penanganan Diabetes mellitus (DM) 
Jurnal Ners Vol. 12 No. 1 April 2017: 88-98

tipe 2 oleh dokter keluarga di Kecamatan Turi Kabupaten Sleman DIY. Universitas Gadjah Mada.

Shaw, J.E., Sicre, R.A., \& Zimmet, P., 2010. Diabetes Research and Clinical Practice Global estimates of the prevalence of diabetes for 2010 and 2030. Diabetes Research and Clinical Practice, 87, pp.414.
Sul-Sel., D.P., 2014. Profil Kesehatan Pemerintah Provinsi Sul-Sel, Sulawesi Selatan: Dinkes Pemprov Sul-Sel.

Yoga, A., Julianti, H.P., \& Pramono, D., 2011. Hubungan antara 4 Pengelolaan Diabetes mellitusdengankeberhasilanpengelolaan DM tipe 2, Semarang: Program Pendidikan Sarjana Kedokteran Umum. 